\title{
INFLUENCE OF BACTERIOCINS PRODUCED BY LACTOBACILLUS PLANTARUM BN IN THE SHELF-LIFE OF REFRIGERATED BOVINE MEAT
}

\author{
Ângela M. Fiorentini' ${ }^{1}$; Ernani S. Sant'Anna ${ }^{2 *}$; Anna C.S. Porto ${ }^{2}$; \\ Jaciara Z. Mazo²; Bernadette D.G.M. Franco ${ }^{3}$ \\ ${ }^{1}$ Departamento de Biologia e Química, UNIJUI, Juí, RS, Brasil. ²Departamento de Ciência e Tecnologia de Alimentos, \\ Centro de Ciências Agrárias, Universidade Federal de Santa Catarina, Florianópolis, SC, Brasil. \\ ${ }^{3}$ Faculdade de Ciências Farmacêuticas, Universidade de São Paulo, São Paulo, SP, Brasil.
}

Submitted: October 18, 2000; Returned to authors for corrections: December 06, 2000; Approved: January 18, 2001

\begin{abstract}
Sugar cane molasses is a cheap by-product of the sugar cane industry. This product was used for growth and production of bacteriocins by Lactobacillus plantarum $\mathrm{BN}$ and evaluated for its potential application in the extension of the shelf-life of raw meat. Bovine meat cubes were dipped in the filtered and neutralized supernatant of the fermented broth (Treatment A) and stored at $5^{\circ} \mathrm{C}$. Counts of psychrotrophic and mesophilic aerobic microorganisms, $\mathrm{pH}$ determination and total acidity were performed on meat cubes after $0,3,6,9,12$ and 15 days. These determinations were also done in cubes dipped in a $6 \%$ lactic acid solution (treatment B) and distilled water (treatment $\mathrm{C}$ ). After 3 days, the counts of psychrotrophic microorganisms in cubes submitted to treatment A, B and C increased 0.38, 1.42 and $2.04 \log$ cycles, respectively. The same happened with mesophilic microorganisms $(0.31,0.33$ and 1.04 log cycles increases, respectively). On the sixth day, the psychrotrophic population in samples submitted to treatments A and B were 2.07 and 0.64 log cycles, respectively, lower than in the control samples (treatment C). Mesophilic microorganisms in these samples were 1.58 and $1.12 \log$ cycles, respectively, lower than the controls. On the sixth day, only samples submitted to treatment A presented lower counts than those recommended by ICMSF as quality standards for raw meat $\left(<10^{7} \mathrm{CFU} / \mathrm{g}\right)$. After nine days of storage under refrigeration, samples submitted to treatment A still maintained acceptable quality. From the twelfth day on, all samples exceeded the microbial quality limits. These results indicate that dipping of raw meat in filtered sugar cane molasses containing bacteriocins produced by L. plantarum $\mathrm{BN}$ may be an interesting technological option to extend the shelf life of refrigerated bovine meat.
\end{abstract}

Key words: Lactobacillus plantarum BN, bacteriocins, bovine meat, shelf-life

\section{INTRODUCTION}

Due to the chemical composition and biological characteristics, meat is an excellent environment for microbial growth. The initial microbiota varies and contains mesophilic and psychrotrophic bacteria which can cause infections in humans and animals and spoilage of the meat. Thus, good manipulation practices and proper conservation methods are needed to put back or to inhibit the microbial growth (7).
Although inadequate to control the growth of psychrotrophic pathogens, refrigeration is the most used conservation method in the meat industry (13).

Biopreservation is a widely accepted conservation system, since it is a natural procedure to control growth of pathogenic and deteriorating microorganisms in refrigerated foods. Biopreservation provides conditions to extend the shelf-life and to increase food safety by means of either the natural microbiota or the antimicrobial products produced by these microorganisms

\footnotetext{
* Corresponding author. Mailing address: Departamento de Ciência e Tecnologia de Alimentos, Universidade Federal de Santa Catarina, UFSZ/CCA/CAL, Av. Admar Gonzaga, 1346, Itacorubi, CEP 88034-001.Florianópolis, SC, Brasil.E-mail: ernanis@cca.ufsc.br
} 
in the product (24). Some lactic acid bacteria present in meat produce antimicrobial proteins known as bacteriocins $(9,13)$, some of them with a relatively broad antimicrobial spectrum. Lactobacillus, Leuconostoc, Pediococcus, Streptococcus, Lactococcus, Enterococcus and Carnobacterium are lactic acid bacteria able to produce bacteriocins $(10,12)$.

From a technological point of view, bacteriocins are the most interesting antimicrobial substances produced by lactic acid bacteria. They have additional advantages: they are degraded by proteolytic enzymes in the gastrointestinal tract and are not toxic (8). For a bacteriocin to be used in food as a preservative it has to be non-toxic, stable and highly active, should possess a wide activity spectrum and must not affect the sensory attributes of the food. It also has to be of low cost and simple use (3).

Recently, sugar cane molasses, a cheap by-product of the sugar cane industry, was shown to be a good substrate for the growth of bacteria, such as Micrococcus varians (17), Pediococcus pentosaceus (25), Pediococcus acidilactici (20) and Lactobacillus plantarum BN (6).

The objective of the present work was to evaluate the inhibition of growth of mesophilic and psychrotrophic microorganisms in bovine meat samples dipped in the filtered supernatant of sugar cane molasses broth containing bacteriocins produced by Lactobacillus plantarum BN. A possible extension in the shelf-life of meat samples submitted to this treatment and maintained under refrigeration was ascertained.

\section{MATERIALS AND METHODS}

\section{Microorganism and cultivation media}

The strain Lactobacillus plantarum BN, provided by Prof. Thomas Montville, Ph.D., The State University of New Jersey, NJ, USA, was cultivated in 3\% sugar-cane molasses broth, diluted and enriched as described by Feltrin (5), using a New Brunswick Scientific fermentor (model Bioflo 2000) and an initial inoculum of $10^{6} \mathrm{CFU} / \mathrm{mL}$. The conditions for growth were: temperature $30^{\circ} \mathrm{C} \pm 0.1^{\circ} \mathrm{C}$, agitation $100 \mathrm{rpm}$, aeration $0.7 \mathrm{vvm}$ ( $\mathrm{L}$ air/L medium/ minute) and time 24 hours. The culture was centrifuged at $3000 \mathrm{rpm}$ for 20 minutes. The supernatant was neutralized using $1 \mathrm{~N} \mathrm{NaOH}$ and sterilized by membrane filtration (Millipore, $0.45 \mu \mathrm{m}$ ).

\section{Production of bacteriocins in solid media}

The spot on the lawn technique was used to demonstrate the production of bacteriocins by $L$. plantarum $\mathrm{BN}(5,14,15)$. The strain was cultivated in MRS broth with $0.5 \%$ glucose at $30^{\circ} \mathrm{C}$ for 24 hours. Two microliters of this broth were transferred to the center of a plate containing Tryptic Soy Agar supplemented with $0.6 \%$ yeast extract (TSAYE). After incubation at $5^{\circ} \mathrm{C} \pm 1^{\circ} \mathrm{C}$ for 4 days, an overlay of Brain Heart Infusion containing $1 \%$ agar and $10^{4}-10^{5} \mathrm{CFU}$ of Lactobacillus sakei ATCC 15521 per $\mathrm{mL}$ was added. The plates were incubated at $30^{\circ} \mathrm{C}$ for 24 hours under anaerobiosis. An inhibitory halo around the growth of L. plantarum $\mathrm{BN}$ indicated the presence of bacteriocins.

\section{Production of bacteriocins in sugar cane molasses broth}

The well diffusion method (13) was used for detection of production of bacteriocins by $L$. plantarum $\mathrm{BN}$ in the sugar cane molasses broth. The neutralized and filtered supernatant $(40 \mu \mathrm{l})$ was added to wells cut in BHI agar (BHI plus $1 \%$ agar) plates containing $10^{4}-10^{5} \mathrm{CFU}$ of L. sakei ATCC 15521 per $\mathrm{mL}$. The plates were kept under refrigeration for one hour and then incubated at $30^{\circ} \mathrm{C}$ for 24 hours, under anaerobiosis. The halo around the well indicated the presence of the inhibitory product in the supernatant.

\section{Treatment of meat samples}

Samples of bovine semitendinosus muscle were purchased from local meat stores, and cut in cubes of approximately 50 g. Twenty meat cubes were submitted to one of three treatments $\mathrm{A}, \mathrm{B}$ or $\mathrm{C}$, as follows:

Treatment A: meat cubes were dipped for 5 minutes in the filtered supernatant of the sugar cane molasses fermented broth. After drained for 2 minutes, each cube was transferred into a sterile plastic bag and kept under refrigeration $\left(5^{\circ} \mathrm{C} \pm 1^{\circ} \mathrm{C}\right)$. On days 3, 6, 9, 12 and 15, three cubes were removed from the refrigerator and submitted to microbiological evaluation and determinations of $\mathrm{pH}$ and total acidity.

Treatment B: bovine meat cubes were dipped in sterile $6 \%$ aqueous commercial lactic acid solution (Vetec). The next steps were the same as for treatment A.

Treatment $C$ : meat cubes were dipped in sterile distilled water (controls). The next steps were the same as described for treatment $\mathrm{A}$.

Each experiment was repeated three times.

\section{Microbiological evaluation (1)}

On days $0,3,6,9,12$ and 15 , cubes of treated meat were withdrawn from the refrigerator and submitted to counts of psychrotrophic and mesophilic microorganisms. Each cube was weighed and homogenized in a Stomacher (Seward Medical, UK) with buffered peptone water, in a 1:10 proportion. Further decimal dilutions up to $10^{-5}$ were performed using the same diluent. $0.1 \mathrm{~mL}$ of each dilution was surface plated in Plate Count Agar for counts of psychrotrophic microorganisms. Counts of mesophilic microorganisms were done pour-plating $1 \mathrm{~mL}$ of each dilution in Plate Count Agar. Each plating was done in duplicate. Incubation was done at $35^{\circ} \mathrm{C}$ for $48 \mathrm{~h}$. Results corresponded to the average counts and were expressed in log units. 


\section{Determination of $\mathbf{p H}$ and total acidity (2)}

On days $0,3,6,9,12$ and 15 , all meat cubes were submitted to determinations of $\mathrm{pH}$ and total acidity in lactic acid using AOAC methods (No. 32010 and No. 16276, respectively).

\section{RESULTS AND DISCUSSION}

The capability of Lactobacillus plantarum $\mathrm{BN}$ to produce bacteriocins was observed both in solid media and in sugar cane molasses broth. The strain grew well and produced bacteriocins at $5^{\circ} \mathrm{C}$, as previously shown by Okereke and Montville who demonstrated activity of bacteriocins produced by L. plantarum $\mathrm{BN}$ at $4^{\circ} \mathrm{C}$ and $10^{\circ} \mathrm{C}$ in solid media (19). Using the spot on the lawn test, Lewus and Montville determined the influence of the temperature on bacteriocins production, observing that the largest production occurred at $15^{\circ} \mathrm{C}$, followed by $10^{\circ} \mathrm{C}, 4^{\circ} \mathrm{C}$ and $30^{\circ} \mathrm{C}$ (15). The psychrotrophic characteristic of this strain makes it potentially useful for the control of growth of microorganisms in refrigerated meat products.

Very good growth of L. plantarum BN was achieved in $3 \%$ sugar-cane molasses broth, diluted and enriched according to Feltrin (6). Lewus and Montville had already observed bacteriocins production by this strain in many media, including ATP broth (All Purpose Tween), TSB (Tryptic Soy Broth) without dextrose supplemented with $1 \%$ glucose and $2 \%$ yeast extract, BHI and BHI supplemented with $2 \%$ yeast extract (15).

For an effective bioconservation of refrigerated food products, the organism should grow, produce antimicrobial substances and have psychrotrophic characteristics (16). Lactic acid bacteria, such as L. plantarum $\mathrm{BN}$, originally isolated from a meat product will probably be more useful in meat products than in other foods, because it is better adapted, and has a competitive advantage when compared to lactic bacteria from other origins (7).

Figs. 1 and 2 show the counts of psychrotrophic and mesophilic bacteria during storage of meat cubes submitted to treatments $\mathrm{A}$, $\mathrm{B}$ and $\mathrm{C}$ under refrigeration. As shown, the psychrotrophic and mesophilic bacterial counts (log) performed in the raw material (day 0) were 3.56 and 5.34, respectively. Both counts were high, but still in agreement with ICMSF standards for acceptable quality for consumption, i.e, $<10^{7} \mathrm{CFU} / \mathrm{g}$ (11).

After 3 days under refrigeration, the counts of psychrotrophic microorganisms in meat cubes submitted to treatment A increased $0.38 \log$ cycles, while in those submitted to treatments B and C the increases were 1.42 and $2.04 \log$ cycles, respectively. In relation to mesophilic microorganisms, cubes submitted to treatments A and B presented similar results, increasing 0.31 and $0.33 \log$ cycles in three days, respectively. Treatment $\mathrm{C}$ (immersion in water) resulted in an increase of 1.04 log cycles in this period, granting marginal quality to the samples.

On the sixth day of storage under refrigeration, the psychrotrophic and mesophilic bacterial population $(\log )$ of samples dipped in water only (treatment C) were 6.90 and
7.43 , respectively. These values correspond to beginning of deterioration $(7,12)$. After six days of storage, the increases in counts in cubes submitted to treatments A and B were 2.07 and $0.64 \log$ cycles for psychrotrophic microorganisms, respectively, and 1.58 and $1.12 \mathrm{log}$ cycles for mesophilic bacteria, respectively, in relation to samples of treatment $\mathrm{C}$. According to ICMSF, $10^{7} \mathrm{CFU} / \mathrm{g}$ is the maximum limit for aerobic counts in chilled carcasses, so meat cubes submitted to treatment $\mathrm{C}$ became unacceptable for consumption in six days at $5^{\circ} \mathrm{C}$ while in those submitted to treatments $\mathrm{A}$ and $\mathrm{B}$, which contained antimicrobial substances, the counts were lower, extending the shelf-life.

From the ninth day of storage on, the psychrotrophic and mesophilic bacteria population in cubes submitted to treatment B exceeded the quality limits ( $>10^{7} \mathrm{UFC} / \mathrm{g}$ ). For this period of

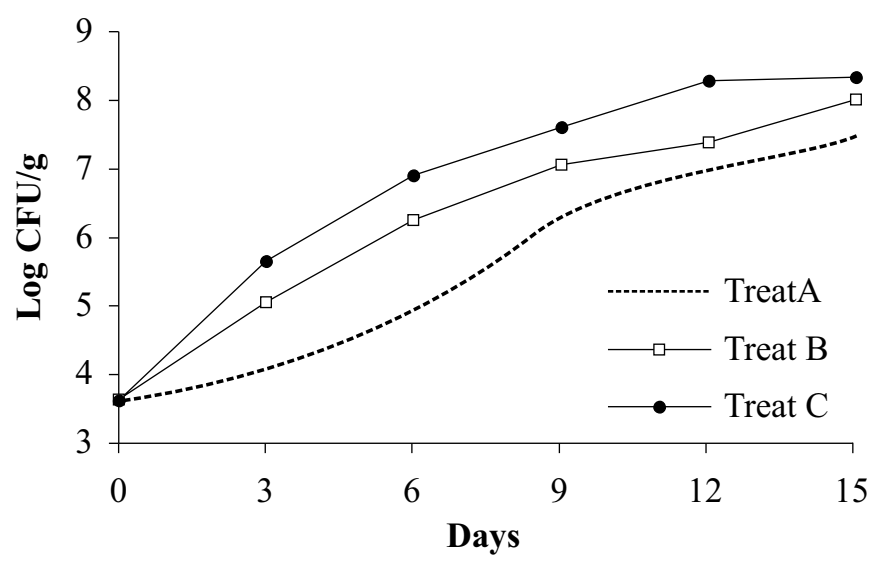

Figure 1. Psychrotrophic microorganisms counts of bovine semitendinosus muscle submitted to three treatments and stored at $5^{\circ} \mathrm{C}(\mathrm{Log} \mathrm{UFC} / \mathrm{g})$.

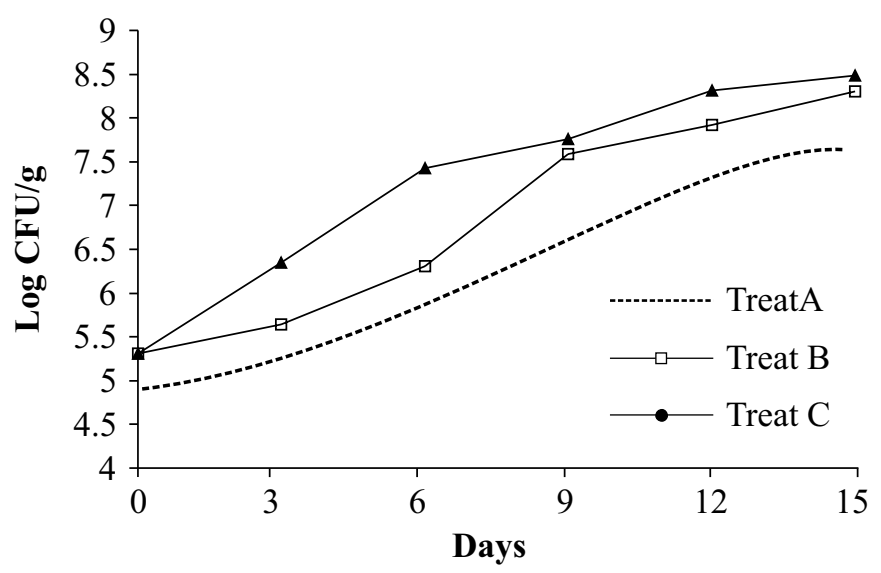

Figure 2. Mesophilic aerobic microorganisms counts (Log $\mathrm{CFU} / \mathrm{g}$ ) of bovine semitendinosus muscle submitted to three treatments and stored at $5^{\circ} \mathrm{C}$. 
storage, the psychrotrophic and mesophilic counts (log) in samples submitted to treatment A were 6.32 and 6.65, which are lower than the acceptable standards of quality. From the twelfth day on, all meat samples, regardless the treatment, surpassed the microbiological limits proposed by the ICMSF (11).

Results show that dipping refrigerated bovine meat in sugarcane molasses broth containing bacteriocins produced by $L$. plantarum $\mathrm{BN}$ can extend the shelf-life of the refrigerated raw bovine meat from three to nine days.

The efficiency of bacteriocins produced by L. plantarum BN is affected by the variability and inconsistency of production. Lewus and Montville (16) observed that it was difficult to obtain active bacteriocin in broth, and that not always good growth conditions of the microorganism meant good production of bacteriocins. In spite of being a broth and used at $30^{\circ} \mathrm{C}$, which is the best temperature for growth but not for bacteriocin production, sugar cane molasses broth containing bacteriocins was effective in reducing the counts of undesirable microorganisms in meat samples dipped in it.

Bacteriocins produced by other lactic acid bacteria have been demonstrated to have application in enhancing quality and safety of meat products. Pediocin PA-1, produced by Pediococcus acidilactici, showed bactericide effect on L. monocytogenes in fresh meat (18). Application of 5.000 AU/mL caused a significant reduction in the bacterial population in meat (2.7 logs in 7 days).

Schillinger and Lucke observed that sakacin A, produced by L. sakei Lb 706, inhibited L. monocytogenes in fresh ground meat stored at $8^{\circ} \mathrm{C}$ up to one week (22). These authors observed that in MRS broth $99.9 \%$ of the Listeria population was destroyed in 24 hours. This shows that L. sakei Lb 706 has a bactericide action in broth, but in the meat it has a bacteriostatic effect.

Lewus and Montville verified that bacteriocins produced by L. plantarum $\mathrm{BN}$ in solid media possessed bactericide action and maintained some activity after heating at $60^{\circ} \mathrm{C}$ for 10 minutes or $100^{\circ} \mathrm{C}$ for 5 minutes $(15)$.

Bacteriocins produced by L. plantarum $\mathrm{BN}$ in sugar cane molasses broth, when applied to bovine semitendinosus muscle, inhibited the multiplication of psychrotrophic and mesophilic aerobic bacteria up to nine days. During storage under refrigeration, bacterial counts in treated meat samples varied only a little, presenting a slow multiplication when compared to the untreated control.

A similar effect was observed by Skytta, Hereijgers and Mattila-Sandholm in ground meat using a supernatant containing bacteriocins from a Pediococcus damnosus culture (21). The bacteriocins inhibited the multiplication of L. monocytogenes for up to 2 weeks. In a similar way, De Martinis and Franco reported that bacteriocins produced by a meat strain of Lactobacillus sake (L. sake 2a) were able to inhibit growth of $L$. monocytogenes in a pork meat product (5). These authors also observed that this bacteriocin was effective against other pathogens in culture media (4).

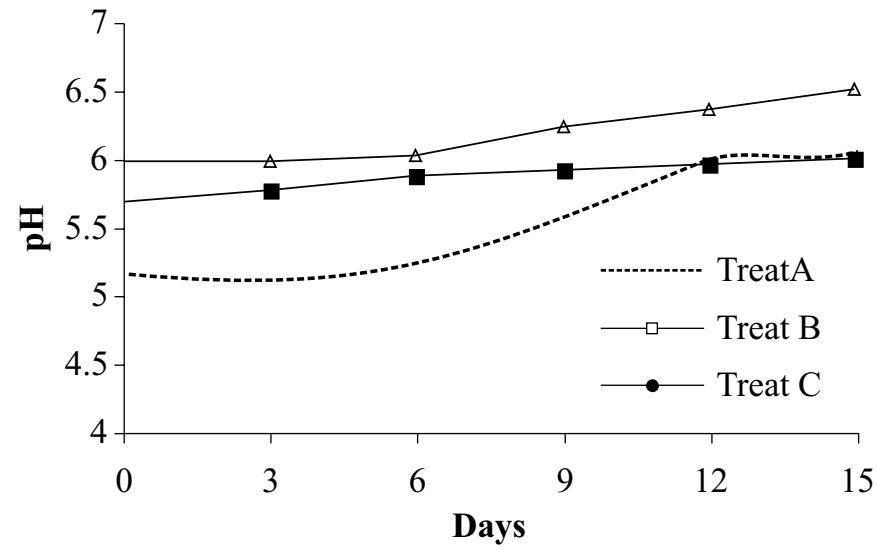

Figure 3. $\mathrm{pH}$ values of bovine semitendinosus muscle submitted to three treatments and stored at $5^{\circ} \mathrm{C}$.

However, use of bacteriocins in meat products should be done carefully because intrinsic characteristics of this product can influence the activity of the bacteriocin. It has been shown that bacteriocins may be inactivated by adsorption to meat and lipid particles (4).

The production of other antimicrobial metabolites in sugar cane molasses should be also taken into account. As a carbohydrate-rich substrate, the production of lactic acid may have an additional antimicrobial effect, which may masks the antimicrobial activity of the bacteriocins produced in sugar cane molasses. In this research, the effect of this acid on inhibition of bacterial growth was evaluated by dipping meat cubes in a solution of lactic acid (treatment B). As shown in Figs. 1 and 2, the antimicrobial activity of lactic acid alone was much lower than that of the bacteriocin. Nevertheless, lactic acid is frequently used in meat industries for its bactericidal effect on spoilage microorganisms, in spite of the high cost (23).

Fig. 3 shows the variation in $\mathrm{pH}$ during storage of meat cubes submitted to treatments $\mathrm{A}, \mathrm{B}$ and $\mathrm{C}$. Initial $\mathrm{pH}$ of the meat was 6.07. After immersion in the sugar cane molasses (Treatment A) and lactic acid solution (Treatment $\mathrm{B}$ ), the $\mathrm{pH}$ decreased to 5.81 and 5.26, respectively. In the controls (Treatment $\mathrm{C}$ ), the $\mathrm{pH}$ stayed at 6.08. During storage under refrigeration, the increase of $\mathrm{pH}$ in meat samples of treatments was directly related to the multiplication of psychrotrophic and mesophilic microorganisms, and associated to autolytic reactions which result in basic compounds that increase the $\mathrm{pH}$. Later on, the proteolytic action of spoilage bacteria also provokes the same effect (20). As to the total acidity of the samples during storage, only a slight variation was observed: it varied between 0.8 and 1.2, in samples submitted to the three treatments.

Results of growth of psychrotrophic and mesophilic microorganisms in the meat samples dipped in sugar-cane molasses broth containing bacteriocins produced by Lactobacillus plantarum $\mathrm{BN}$ indicate that the shelf-life of this product under refrigeration 
$\left(5^{\circ} \mathrm{C}\right)$ can be extended up to nine days. Treatment with fermented and filtered sugar cane molasses may be an interesting tool to the control of microbial growth in this perishable product.

\section{RESUMO}

\section{Influência de bacteriocinas produzidas por Lactobacillus plantarum BN na vida útil de carne bovina refrigerada}

Melaço de cana de açúcar é um sub-produto barato da indústria açucareira. Esse produto foi empregado para o crescimento e produção de bacteriocina de Lactobacillus plantarum $\mathrm{BN}$ e avaliado quando a sua aplicação potencial no aumento da vida útil de carne crua. Cubos de carne bovina foram imersos por 5 minutos no sobrenadante filtrado e neutralizado dessa cultura (Tratamento A) e mantidos a $5^{\circ} \mathrm{C}$. Contagens de microrganismos psicrotróficos e mesófilos, determinação de $\mathrm{pH}$ e de acidez total foram realizadas nas amostras após 0, 3, 6, 9, 12 e 15 dias. Essas determinações foram também feitas em amostras mergulhadas por 5 minutos em solução de ácido lático a 6\% (tratamento B) e em água destilada (tratamento C). Após 3 dias em refrigeração, as contagens de microrganismos psicrotróficos nas amostras submetidas ao tratamento A aumentaram 0,38 ciclos log, enquanto aquelas submetidas aos tratamentos B e C aumentaram muito mais (1,42 and 2,04 ciclos $\log$, respectivamente). O mesmo aconteceu com os microrganismos mesófilos $(0,31,0,33$ and 1,04 ciclos log, respectivamente). No sexto dia, as contagens de psicrotróficos nas amostras submetidas aos tratamentos A e B foram 2,07 e 0,64 ciclos $\log$, respectivamente, mais baixas que nas amostras controle (tratamento C). As contagens de mesófilos nessas amostras foram 1,58 e 1,12 ciclos log, respectivamente, mais baixas que nos controles. No sexto dia, somente as amostras submetidas ao tratamento A apresentaram contagens inferiores a aquelas consideradas pelo ICMSF como padrão de qualidade $\left(<10^{7} \mathrm{UFC} / \mathrm{g}\right)$. Após 9 dias, somente as amostras tratadas com a bacteriocina apresentaram qualidade aceitável. A partir do $12^{\circ}$ dia, todas as amostras de carne estavam fora dos padrões de qualidade. Esses resultados indicam que a imersão da carne bovina em caldo de melaço de cana de açúcar pode ser um interessante recurso tecnológico para aumentar a vida útil desse produto em refrigeração.

Palavras-chave: Lactobacillus plantarum BN, bacteriocinas, carne bovina, vida útil

\section{REFERENCES}

1. American Public Health Association. Compendium of Methods for the Microbiological Examination of Food. 3.ed. Washington : APHA, 1992, 1219 p.
2. Association of Official Analytical Chemists. Official Methods of Analysis, 14.ed. Arlington, 1984, 1141p.

3. Daeschel, M.A. Application of bacteriocins in food systems. In: ShainDow Kung (ed). Biotechnology and Food Safety, London:Butterworths, 1990.

4. De Martinis, E.C.P.; Franco, B.D.G.M. Inhibition of foodborne pathogens by bacteriocin producing Leuconostoc sp. and Lactobacillus sake isolated from linguiça frescal. Rev. Microbiol., 28: 284-287, 1997.

5. De Martinis, E.C.P.; Franco, B.D.G.M. Inhibition of Listeria monocytogenes in a pork product by a Lactobacillus sake strain. Int. J. Food Microbiol. 42: 119-126, 1998

6. Feltrin, V.P. Produção de Lactobacillus plantarum em meio de cultura à base de melaço de cana-de-açúcar. Florianópolis, 1997, 60p. (M.Sc. Thesis. Universidade Federal de Santa Catarina UFSC).

7. Garcia, T.; Martin, R.; Sanz, B.; Hernandez, P.E. Extensión de la vida útil de la carne fresca. In: Envasado en atmósfera modificadas y utilización de bacterias lácticas y bacteriocins. Rev. Espanõla de Cienc. Tecnol. Al., 35: $1-18,1995$.

8. Guerrero, I.; Mendiolea, E.P.; Prado, A. Inoculation of lactic acid bacteria on meat surfaces as a means of descontamination in semitropical conditions. Meat Sci., 40: 397-411, 1995.

9. Hernandéz, P.E.; Rodriguez, J.M.; Cintas, J.M. et al. Utilización de bacterias lácticas en el control de microorganismos patógenos de los alimentos. Microbiologia SEM, 9: 37-48, 1993.

10. Hugas, M. Bacteriocinogenic lactic acid bacteria for the biopreservation of meat and meat products. Meat Sci., 49: 139-150, 1998.

11. Internacional Commission on Miicrobiological Specifications for Foods (ICMSF). Microorganisms de los alimentos - Métodos de muestro para análises microbiológicas: Principios y aplicaciones especificas. Vol.II. Acribia, Zaragoza, 1978.

12. Lenz, G.; Terra, N.N.; Garcia, S. A ação do ácido láctico na conservação de carcaças de frangos resfriadas. Rev. Nac. Carne, 16: 10-14, 1992.

13. Lewus, C.B.; Kaiser, A.; Montville, T.J. Inhibition of food-borne bacterial pathogens by bacteriocins from lactic acid bacteria isolated from meat. Appl. Environ. Microbiol., 57: 1683-1688, 1991.

14. Lewus, C.; Montville, T. Detection of bacteriocins produced by lactic acid bacteria. J. Microbiol. Meth., 13: 45-150, 1991.

15. Lewus, C.; Montville, T. Further characterization of bacteriocins plantaricin BN, Bavaricin MN and Pediocin A. Food Biotech., 6: 153174, 1992.

16. McMullen, L.M.; Stiles, M.E. Potencial for use of bacteriocin-producing lactic acid bacteria in the preservation of meats. J. Food Prot., 55 (Suppl), 64-71, 1996.

17. Miranda, L.A.S.; Sant'Anna, E.S.; Porto, A.C.S. The growth of Micrococcus varians by utilizing sugar cane blackstrap molasses as substrate. Rev. Microbiol., 30: 125-129, 1999

18. Nielsen, J.W.; Dickson, J.S.; Crouse, J.D. Use of a bacteriocin produced by Pediococcus acidilactici to inhibit Listeria monocytogenes associated with fresh meat. Appl. Environ. Microbiol., 56: 2142-2145, 1990.

19. Okereke, A.; Montville, T.J. Bacteriocin inhibition of Clostridium botulinum spores by lactic acid bacteria. J. Food Prot., 54: 349-353, 1991.

20. Sant'Anna, E.S.; Torres, R.C.O. Growth of Pediococcus acidilactici on sugar cane blackstrap molasses. Rev. Microbiol., 29: 202-207, 1998.

21. Skitta, E.; Hereijgers; Mattila-Sandholm, W. Broad spectrum antibacterial activity of Pediococcus damnosus and Pediococcus pentosaceus in minced meat. Food Microbiol., 8: 231-237, 1991.

22. Schillinger, U.; Lücke, F. Behaviour of L.monocytogenes in meat and its control by a bacteriocin-producing strain of Lactobacillus sake. J. Appl. Bacteriol., 70: 473-478, 1991.

23. Silva, J.A.; Beraquet, N.J. Redução da contaminação inicial de carne bovina pela sanitização com ácidos orgânicos. Bol. Ceppa, 15: 127-142, 1997.

24. Stiles, M.E.; Hastings, J.W. Bacteriocin production by lactic acid bacteria: potencial for use in meat preservation. Trends Food Sci. Technol., 2: 247251, 1991.

25. Villavicencio, A.R.N. Avaliação da utilização de melaço de cana de açúcar como substrato para o crescimento de Pediococcus pentosaceus. Florianópolis, 1996, 88p. (Ms.S. Thesis. Universidade Federal de Santa Catarina, UFSC). 